\title{
Temporomandibular joint arthrocentesis: a technique proposal. Case report
}

\author{
Artrocentese da articulação temporomandibular: uma proposta de técnica. Relato de caso
}

Eduardo Grossmann¹, Rodrigo Lorenzi Poluha², João Paulo Bezerra Leite ${ }^{3}$

DOI 10.5935/2595-0118.20190052

\section{ABSTRACT}

BACKGROUND AND OBJECTIVES: Arthrocentesis is an effective treatment to reduce or eliminate pain, increase maximal interincisal distance, and to eliminate joint effusion in patients with disc displacement without reduction. This study aims to expose and to discuss a new technique proposal of temporomandibular joint arthrocentesis applied in the treatment of a single case of disc displacement without reduction.

CASE REPORT: Female patient, 18-year-old patient sought treatment due to joint pain and mouth opening limitation. The maximal interincisal distance was $30.28 \mathrm{~mm}$. Magnetic resonance imaging confirmed the diagnosis of disc displacement without reduction with signs of joint effusion in the right temporomandibular joint. Temporomandibular joint arthrocentesis was performed under selective sensory nerve block of the auriculotemporal, the masseteric and posterior deep temporal nerves. Two needles were inserted in the upper compartment of the temporomandibular joint. In the second needle, a transparent catheter was connected into a vacuum pump. Clinically, after the arthrocentesis, the maximal interincisal distance increased to $46.25 \mathrm{~mm}$, and the patient referred no more pain. After six months, a magnetic resonance imaging was performed to observe the results, and there were no more signs of joint effusion. CONCLUSION: Temporomandibular joint arthrocentesis was an effective treatment for this patient with disc displacement without reduction. The aspect of this technique that is particularly relevant for clinical practice was the connection of a transparent catheter to a vacuum pump. In fact, it allowed the visualization of the solution fluidity, as well as guides the flow of

Eduardo Grossmann - (Dhttps://orcid.org/0000-0002-1238-1707;

Rodrigo Lorenzi Poluha - Dhttps://orcid.org/0000-0001-7180-6448;

João Paulo Bezerra Leite - (Dhttps://orcid.org/0000-0001-9367-9830.

1. Universidade Federal do Rio Grande do Sul. Departamento de Odontologia, Porto Alegre, RS, Brasil.

2. Universidade de São Paulo, Faculdade de Odontologia de Bauru, Departamento de Prótese, Bauru, SP, Brasil.

3. Biopain Institute, São Paulo, SP, Brasil.

Submitted on January 05, 2019.

Accepted for publication on July 09, 2019.

Conflict of interests: none - Sponsoring sources: None.

Correspondence to:

Eduardo Grossmann

Rua Ramiro Barcelos, 2492

90035-004 Porto Alegre, RS, Brazil.

E-mail: edugdor@gmail.com

(C) Sociedade Brasileira para o Estudo da Dor the solution used for joint washing, optimizing the irrigation. However, new studies are necessary to compare different protocols of irrigation with and without the associated use of a vacuum pump.

Keywords: Articular disc displacement without reduction, Arthrocentesis, Temporomandibular joint.

\section{RESUMO}

JUSTIFICATIVA E OBJETIVOS: A artrocentese e um tratamento eficaz para diminuir ou abolir a dor, aumentar a máxima distância interincisal e eliminar o derrame articular em pacientes com deslocamento de disco sem redução. $\mathrm{O}$ objetivo deste estudo foi expor e discutir uma nova proposta técnica de artrocentese da articulaçáo temporomandibular aplicada no tratamento de um caso de deslocamento de disco sem redução.

RELATO DO CASO: Paciente do sexo feminino, 18 anos procurou tratamento devido a dor na articulação temporomandibular e limitação da abertura da boca. A distância interincisal máxima foi de $30,28 \mathrm{~mm}$. A ressonância magnética confirmou o diagnóstico de deslocamento de disco sem redução com sinais de derrame articular na articulação temporomandibular direita. A artrocentese foi realizada com o bloqueio anestésico do nervo auriculotemporal, masseterino e temporal profundo posterior. Depois disso, duas agulhas foram inseridas no compartimento superior da articulação temporomandibular. Na segunda agulha foi conectado um cateter transparente e nesse uma bomba de vácuo. Clinicamente, após a artrocentese, a distância interincisal máxima aumentou para $46,25 \mathrm{~mm}$ e não houve mais dor. $\mathrm{Na}$ nova ressonância magnética realizada 180 dias após, não havia mais sinais de derrame articular.

CONCLUSÃO: A artrocentese da articulação temporomandibular foi eficaz no tratamento do paciente com deslocamento do disco sem redução. $\mathrm{O}$ aspecto dessa técnica, que é particularmente relevante para a prática clínica, foi a conexão de um cateter transparente a uma bomba de vácuo. Isso permitiu a visão da solução, sua fluidez, além de orientar o fluxo da solução utilizada para lavagem, otimizando a irrigação. No entanto, novos estudos são necessários para comparar diferentes protocolos de irrigação com e sem o uso associado de uma bomba de vácuo.

Descritores: Articulação temporomandibular, Artrocentese, Deslocamento do disco articular sem redução.

\section{INTRODUCTION}

The arthrocentesis technique was first described in 1991 by Nitzan, Dolwick and Martinez ${ }^{1}$. It is an effective and minimally invasive method for treatment of several temporoman- 
dibular joint (TMJ) disorders ${ }^{2}$. It consists of washing the superior compartment of the TMJ without direct visualization. The washing procedure is done with a biocompatible substance, such as saline, which helps the dilution of the local allogenic substances and frees the joint disc by removing the adhesions formed between the surfaces of the disc and the mandibular fossa due to the hydraulic pressure generated by the irrigation process ${ }^{1,3}$. The literature has reported some risks with the conventional technique ${ }^{3}$, such as facial nerve paresis, by anesthetic block ${ }^{4}$. Also, there is a risk of extravasation of the liquid used during the irrigation to the surrounding tissue; since there is no guarantee that even using two needles, it is not possible to wash out all the liquid inside. Such risks can be avoided by modifying the technique.

This study aims to expose and discuss a technical proposal of temporomandibular joint arthrocentesis.

\section{CASE REPORT}

Female patient, 18-year-old, sought treatment due to joint pain and mouth opening limitation. No relevant medical condition was reported. The patient had a history of clicking sound in her right TMJ for the past 10 years. The click disappeared one year ago. Since then, the patient has been unable to open her mouth completely and complained of localized pain in the right TMJ region. On clinical examination, the maximal interincisal distance was $30.28 \mathrm{~mm}$ with a jaw deflected to the affected side during the opening. Also, the patient was able to perform a normal lateral movement to the affected side. However, there was a limited, painful lateral excursion to the unaffected side. A magnetic resonance imaging (MRI) was requested and the diagnosis of disc displacement without reduction (DDWOR) with signs of joint effusion in the right TMJ was confirmed. The left TMJ did not show clinical or MRI dysfunction. The patient did not respond well to the conservative treatment provided for three months (splint, anti-inflammatory drugs, soft diet, and individualized physiotherapy). Thus, a TMJ arthrocentesis was performed by an experienced maxillofacial surgeon. Clinically, after the arthrocentesis, the maximal interincisal distance increased to $46.25 \mathrm{~mm}$, with no more pain. The patient was followed for $7,14,30,60,90,180$, and 360 days after the procedure. No complications were reported. The results were maintained in all follow-ups. A new MRI was performed 180 days after the arthrocentesis. There were no more signs of joint effusion in the right TMJ. The left TMJ remained unchanged.

\section{Description of the arthrocentesis technique}

In the presented case, the arthrocentesis was performed only once in the right TMJ. A demographic pen was used to draw a straight line from the middle portion of the tragus to the corner side of the eyeball, and two points were marked on this line for the insertion of the needles. The first, the most posterior one, at $10 \mathrm{~mm}$ from the tragus and $2 \mathrm{~mm}$ below the corner-tragus line. The second one was inserted $20 \mathrm{~mm}$ anterior to the tragus and $10 \mathrm{~mm}$ inferior to the corner-tragus line. After waiting for about
3 minutes for the ink to dry, antisepsis of the whole face was performed with chlorhexidine solution at $2 \%$, with emphasis on the preauricular region and ear. Then, a sterile ball of gauze was placed next to the external acoustic meatus, and the whole face was covered by a sterile fenestrated surgical drape, only exposing the joint. The next step was the auriculotemporal nerve block, followed by the anesthesia of the masseteric and posterior deep temporal nerves with lidocaine chloride at $2 \%$ without vasoconstrictor $1: 100.000$, with a total volume of $3.6 \mathrm{~mL}$. The patient was asked to open his mouth to its maximum to allow the jaw head to move down and forward, facilitating the approach to the posterior recess of the upper TMJ compartment. A 40x12mm needle connected to a $5 \mathrm{~mL}$ syringe was inserted into the first mark, and $4 \mathrm{~mL}$ of saline solution at $0.9 \%$ was administered to distend the joint space. A second needle was introduced into the distended compartment, at the point established before, and connected to a \#20 flexible and transparent catheter $(60 \mathrm{~cm})$ connected to a vacuum pump (Kavo', Joinville, Santa Catarina, Brazil), which allowed the visualization of the solution. Afterward, an infusion extender, $15 \mathrm{C}$ of $120 \mathrm{~cm}$ (Compojet, Conceição do Jacuípe, Bahia, Brazil), was connected to a $60 \mathrm{~mL}$ syringe to allow the joint lysis and lavage. A total of $300 \mathrm{~mL}$ of physiological solution was used for the TMJ arthrocentesis. No other substance or drug was added to the solution being injected. Once the procedure was completed, the needles were removed, and the patient was asked to perform opening and lateral movements of the mouth in order to break down any possible disc adherences, in attempt to restore an improved mandibular mobility pattern. Local dressing was conducted with sterile gauze and micropore. On the post-procedure protocol for analgesia, paracetamol $(750 \mathrm{mg})$ every 6 hours orally was suggested for a maximum of three days if necessary and an ice pack to be applied to the intermittently intervened joint for a period of 48 hours. In addition, the patient was advised to take liquid and pasty foods for 96 hours, not to expose himself to the sun, and to undergo no medical/dental procedure while recovering (Figures 1 and 2).

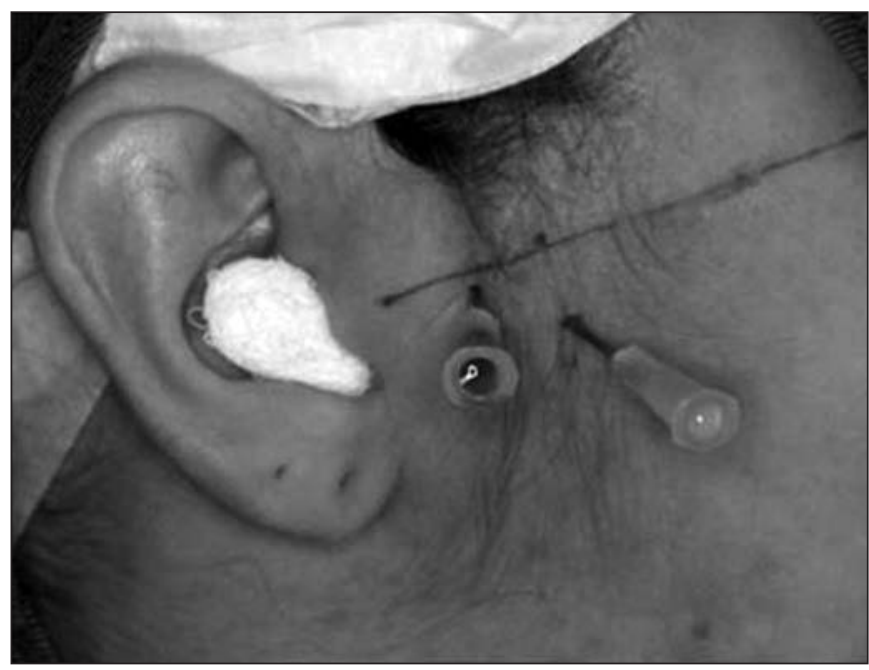

Figure 1. Arthrocentesis technique. Two needles inserted in the previously established points. 


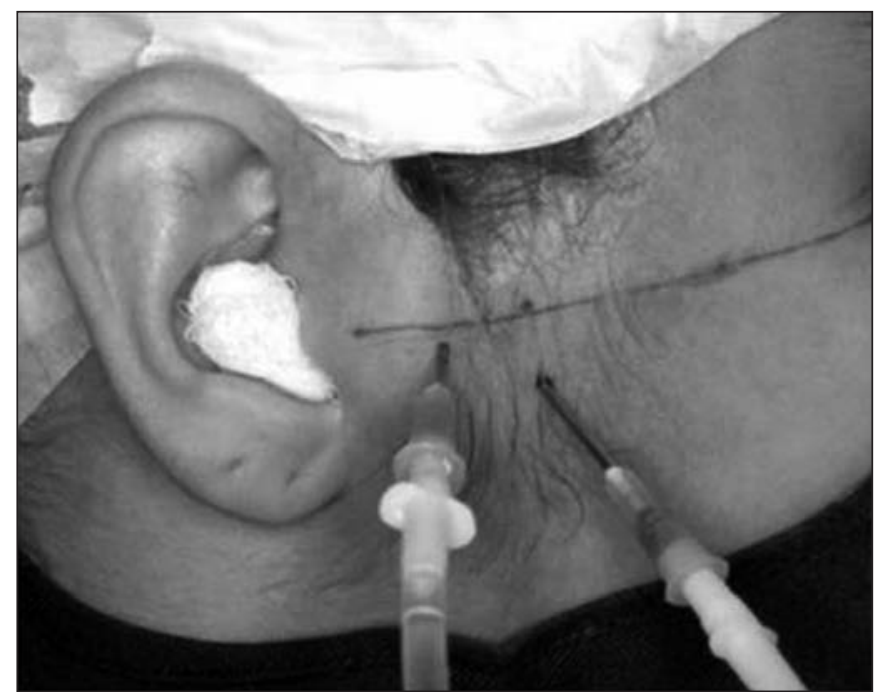

Figure 2. Arthrocentesis technique. Infusion extender and the flexible and transparent catheter connected to the needles.

\section{DISCUSSION}

Arthrocentesis is effective to decrease ou eliminate pain, increase maximal interincisal distance, and to eliminate joint effusion in patients with $\mathrm{DDWOR}^{5-9}$. A draw of a straight line from the middle portion of the tragus to the corner side of the eyeball and anatomical references are enough to mark the two points of insertion of the needles. The literature showed that ultrasound-guided arthrocentesis was no more successful than the conventional technique and took longer ${ }^{10}$.

The auriculotemporal nerve block, followed by the anesthesia of the masseteric and posterior deep temporal nerves was aimed to avoid the discomfort and/or pain due to the hydraulic pressure that could occur at the beginning of the joint washing procedure, thus obtaining excellent analgesia of the region, avoiding the need for sedation. The literature shows inconclusive advantages of performing arthrocentesis under general anesthesia ${ }^{11}$. In addition, our proposed anesthetic sequence reduces the chance of facial nerve paresis because injection is given directly into the trigeminal nerve branches and not intraarticularly into the temporomandibular joint.

The reduction of the pain, the increase of mouth opening, and the reduction of joint effusion are expected as the irrigation process allows the removal of debris of the joint tissues in degeneration process and helps to eliminate the allogenic substances inside the TMJ (mainly, inflammatory mediators) ${ }^{1,12,13}$. Also, the arthrocentesis performed under pressure may help to remove adherences, eliminate the negative pressure in the joint with the distention the joint space, recovering the space of the joint disc and fossa, and changing the viscosity of the synovial liquid that helps the translation of the joint disc and condyle $e^{3,14}$. One of the advantages of the technique proposed in this paper is the use of a flexible and transparent catheter connected to the second needle and a vacuum pump. This appliance allows the visualization of the solution and the fluidity, guides the flow of solution used for joint washing and optimize irrigation regardless of the volume used. Physically this can be explained by the pressure difference ${ }^{15}$ inside and outside of the TMJ during the arthrocentesis. Once the irrigation solution is injected into the upper compartment, a pressure difference is created in relation to the external environment. Thus, the pressure inside the upper compartment gets much higher than on the outside. Due to the tendency to restore the pressure balance, the irrigation solution tends to come out of the upper compartment through the second needle. The efficiency of this process is accentuated by the vacuum pump, that also promotes other benefits already mentioned. Also, it can possibly reduce the risk of extravasation of solution used during irrigation, that already has been associated with a negative effect on the success of the procedure ${ }^{16}$.

\section{CONCLUSION}

Arthrocentesis is a simple, less invasive, and highly effective procedure. The aspect of this technique that is particularly relevant for clinical practice is the optimization of irrigation. However, new studies are necessary to compare different protocols of irrigation with and without the associated use of a vacuum pump.

\section{REFERENCES}

1. Nitzan DW, Dolwick MF, Martinez GA. Temporomandibular joint arthrocentesis: a simplified treatment for severe, limited mouth opening. J Oral Maxillofac Surg. 1991;49(11):1163-70.

2. Bouchard C, Goulet JP, El-Ouazzani M, Turgeon AF. Temporomandibular lavage versus nonsurgical treatments for temporomandibular disorders: a systematic review and meta-analysis. J Oral Maxillofac Surg. 2017;75(7):1352-62.

3. Nitzan DW. Arthrocentesis-incentives for using this minimally invasive approach for temporomandibular disorders. Oral Maxillofac Surg Clin North Am. 2006;18(3):311-28.

4. Vaira LA, Raho MT, Soma D, Salzano G, Dell'aversana Orabona G, Piombino P, et al. Complications and post-operative sequelae of temporomandibular joint arthrocentesis. Cranio. 2018;36(4):264-7.

5. Grossmann E, Poluha RL, Iwaki LCV, Santana RG, Filho LI. Predictors of arthrocentesis outcome on joint effusion in patients with disk displacement without reduction. Oral Surg Oral Med Oral Pathol Oral Radiol. 2018;125(4):382-8.

6. Grossmann E, Poluha RL, Iwaki LCV, Santana RG, Iwaki Filho L. The use of arthrocentesis in patients with temporomandibular joint disc displacement without reduction. PLoS One. 2019;14(2):e0212307

7. Grossmann E, Guilherme Vargas Pasqual P, Poluha RL, Iwaki LCV, Iwaki Filho L, Setogutti ÊT. Single-needle arthrocentesis with upper compartment distension versus conventional two-needle arthrocentesis: randomized clinical trial. Pain Res Manag. 2017;2017:2435263.

8. Pasqual PGV, Poluha RL, Setogutti ÊT, Grossmann E. Evaluation of effusion and articular disc positioning after two different arthrocentesis techniques in patients with temporomandibular joint disc displacement without reduction. Cranio. 2018; 30:1-8. [Epub ahead of print].

9. Folle FS, Poluha RL, Setogutti ET, Grossmann E. Double puncture versus single puncture arthrocentesis for the management of unilateral temporomandibular joint disc displacement without reduction: A randomized controlled trial. J Craniomaxillofac Surg. 2018;46(12):2003-7.

10. Sivri MB, Ozkan Y, Pekiner FN, Gocmen G. Comparison of ultrasound-guided and conventional arthrocentesis of the temporomandibular joint. Br J Oral Maxillofac Surg. 2016;54(6):677-81

11. Tuz HH, Baslarli O, Adiloglu S, Gokturk T, Meral SE. Comparison of local and general anaesthesia for arthrocentesis of the temporomandibular joint. Br J Oral Maxillofac Surg. 2016;54(8):946-9.

12. Kaneyama K, Segami N, Nishimura M, Sato J, Fujimura K, Yoshimura H. The ideal lavage volume for removing bradykinin, interleukin- 6 , and protein from the temporomandibular joint by arthrocentesis. J Oral Maxillofac Surg. 2004;62(6):657-61.

13. Grossmann E, Poluha RL, Iwaki LCV, Iwaki Filho L. Arthrocentesis with different irrigation volumes in patients with disc displacement without reduction: one-year follow-up. Cranio. 2018; 26:1-6. [Epub ahead of print].

14. Yura $S$, Totsuka Y. Relationship between effectiveness of arthrocentesis under sufficient pressure and conditions of the temporomandibular joint. J Oral Maxillofac Surg. 2005;63(2):225-8.

15. Chalmers AF. Qualitative novelty in seventeenth-century science: Hydrostatics from Stevin to Pascal. Stud Hist Philos Sci. 2015;51(1):1-10.

16. Bas B, Yuceer E, Kazan D, Gurbanov V, Kutuk N. Clinical and intra-operative factors affecting the outcome of arthrocentesis in disc displacement without reduction: a retrospective study. J Oral Rehabil. 2019;46(8):699-703. 